\title{
Comparison between building roof construction systems based on the LCA
}

\section{Comparativa entre sistemas constructivos de cubiertas de edificios, según el ACV}

\author{
Manuel J. Carretero-Ayuso (Main autor and Corresponding author) \\ Departamento de Expresión Gráfica. Universidad de Extremadura \\ Avenida de las Letras s/n, 10004 Cáceres (Spain) \\ carreteroayuso@yahoo.com
}

\section{Justo García-Sanz-Calcedo}

Departamento de Expresión Gráfica. Universidad de Extremadura

Avenida de Elvas s/n, 06006 Badajoz (Spain)

jgsanz@unex.es

\author{
Manuscript Code: 912 \\ Date of Acceptance/Reception: 02.04.2018/26.05.2017 \\ DOI: 10.7764/RDLC.17.1.123
}

\begin{abstract}
Based on Life Cycle Assessment techniques, this research compares the environmental impact of 11 variants for the construction of roofs in residential buildings. Among others, the energy used, the carbon footprint and the waste associated to placement and packaging are found, leading to 9 sustainability indicators, which include socio-economic aspects such as the decennial maintenance cost, the maintainability ratio or the quantity of labour necessary. Each of the roofs was characterised based on 20 typologies of constituent layers, categorised under 6 construction functional groups, according to the function held in the roofs. Based on this study, it is demonstrated that the most sustainable roofs are non-trafficable flat roof with gravel finishing (with either a PVC or bituminous layer), followed by pitched roofs (with ceramic and cement mortar tiles) and green roofs with PVC layer. It was noted that trafficable flat roofs generate greater emissions of carbon dioxide and use more energy in their construction, and that flat roofs with gravel finishing require a lower cost of decennial maintenance. Furthermore, pitched roofs generate a higher amount of construction and packaging waste than flat roofs and require more labour, especially in the case of pitched roofs with tiles.
\end{abstract}

Keywords: Building roofs, sustainable design, sustainable construction, ecodesign, maintenance.

\section{Resumen}

En base a las técnicas basadas en el Análisis de Ciclo de Vida, esta investigación compara el impacto medioambiental de 11 variantes constructivas de cubiertas en edificios residenciales. Se determina la energía consumida, la huella de carbono, los residuos de colocación y embalaje y otros varios, hasta valorar 9 indicadores de sostenibilidad, incluyendo aspectos socioeconómicos como el coste decenal de mantenimiento, la ratio de mantenibilidad o la cantidad de mano de obra necesaria. Cada una de las cubiertas se ha caracterizado en base a 20 tipologías de capas constituyentes, que se han agrupado bajo 6 grupos funcionales constructivos, según la función que tuvieran dentro de las cubiertas. En base a este estudio, se ha demostrado que las cubiertas más sostenibles son las cubiertas planas no transitables acabadas en grava (tanto con lámina de PVC como bituminosa), seguidas de las cubiertas inclinadas (de teja de mortero de cemento y cerámica) y de las cubiertas ajardinadas con lámina de PVC. Se observó que la cubierta transitable plana genera mayor emisión de dióxido de carbono y utiliza más energía en su construcción y que las cubiertas planas acabadas con grava requieren un menor coste de mantenimiento decenal. Además, las cubiertas inclinadas generan mayor cantidad de residuos de construcción y de embalaje que las planas y requieren mayor cantidad de mano de obra, especialmente las cubiertas inclinadas de tejas.

Palabras clave: Cubiertas de edificios, diseño sostenible, construcción sostenible, ecodiseño, mantenimiento.

Introduction

Sustainable construction is centred on the development of social, environmental and economic improvements, according to the objectives of sustainable development itself; a building designed and built sustainably will minimise the use of water, raw materials, energy, land, etc., over the course of its service life.

The energy used in the manufacturing and construction processes implies the modification of the environment and brings with it a number of environmental impacts. The building sector represents one of the sectors with highest incidence of $\mathrm{CO}_{2}$ emissions into the atmosphere, mostly caused by the large amounts of energy used by the processes of manufacturing the materials. The construction and maintenance of buildings uses approximately $40 \%$ of the materials employed in the European Union (Baño-Nieva \& Vigil-Escalera del Pozo, 2005).

One of the most representative areas of buildings is its roofs, which makes their life cycle assessment of interest. From the construction point of view, there are two types of roofs: flat roofs (with a slope less than or equal to $5 \%$ ) and pitched roofs (with a slope higher than 5\%) (Ministerio de la Vivienda, 2006). The former can either be ventilated or not. Both of these can in turn be considered 'conventional' (with and without insulation) and 'inverted' (with insulation on top of 
the waterproofing). These latter ones can be prepared with different kinds of waterproofing (bituminous membrane, PVC membrane, liquid waterproofing systems), with the inclusion of separation layers (geotextiles) and with the possibility of being trafficable (whether restricted to pedestrians, for industrial use, for vehicles...) or non-trafficable (with gravel finishing, green roofs...). Finally, pitched roofs can have various slopes, be made with slates, tiles (ceramic or cement mortar, with each having multiple geometric varieties), metallic panels, etc.

Flat roofs have a waterproofing layer ensuring that water does not enter the building (Graus, 2005). This requirement sets them apart from pitched roofs, as the latter do not require said waterproofing membrane so long as the roof plans have a certain minimum slope (Bludau \& Schunck, 2010).

Belando \& López-Mesa (2010) carried out a comparative study of two solutions of flat roofs (conventional vs. inverted), using Life Cycle Assessment (LCA) tools. They demonstrated that inverted roofs are more advantageous than conventional ones, despite the need for an insulating material (extruded polystyrene), with a higher impact than that of the conventional roof with mineral wool. This is due to the fact that, in the inverted roof, the waterproofing membrane's service life is greater, thus reducing the maintenance that is necessary throughout the building's service life.

Fayos Ortega (2013) compared six typologies of flat roofs, studying the depletion of abiotic resources, acidification, eutrophication, destruction of the ozone layer and photochemical oxidation. The best results were obtained by roofs with wooden flooring and by green roofs.

Contarini \& Meijer (2015) compared the materials for various types of flat roofs, applying the LCA to a block of apartments with $300 \mathrm{~m}^{2}$. They evaluated five insulating materials with three different heat resistances each, five types of waterproofing layers, three types of finishing and a green roof. They concluded that an intelligent choice of materials can significantly improve the environmental performance of a building's flat roof.

Vieira Lopes \& Thais (2014) analysed various roof systems to calculate the values for these materials' embodied energy and $\mathrm{CO}_{2}$ emissions. They concluded that three of the green roof systems had better energy efficiency rates and lower $\mathrm{CO}_{2}$ emissions than conventional roofs with ceramic flooring tiles. Thus, these roof systems were regarded as an effective alternative, from the standpoint of the reduction of environmental impact. Chau, Hui, Ng, \& Powell (2012) analysed the $\mathrm{CO}_{2}$ emission of five types of material compositions over the course of 60 years in a building, concluding that reusing construction waste can reduce the $\mathrm{CO}_{2}$ footprint by $5.9 \%$, and that reusing resources and importing materials from the region could reduce the carbon footprint by 3.2 and $3.1 \%$, respectively.

Chenani, Lehvävirta \& Häkkinen (2015) analysed the environmental imp act of two systems of light green roofs, in function of the various layers, concluding that the layers of retention of water, drainage and substratum contained the components with greatest negative environmental impact. Saiz, Kennedy, Bass \& Pressnail (2006) used the LCA to evaluate the benefits of a green roof in a residential building in Madrid, assuming a service life for the building of 50 years. They found the annual energy saving to be of $1 \%$, but the cooling load in the summer is reduced by more than $6 \%$ and reductions in the cooling load in the upper floors of up to $25 \%$ were observed in the peak hours. Also by the means of LCA Peri, Traverso, Finkbeiner \& Rizzo (2012) analysed the environmental impact of green roofs, examining a specific substratum. They studied the substratum's layout and the role of the fertilisers used for the maintenance of the green roof, observing them to play an important role in the entire balance of the life cycle.

Lamnatou \& Chemisana (2015) analysed different types of roofs with installations of photovoltaic panels. It was found that the layout with the least environmental impact considered a photovoltaic installation over a green roof, due to the benefits of the substratum/plant layer which results in an increase of the photovoltaic production (due to evapotranspiration). In turn, Cubi, Zibin, Thompson \& Bergerson (2015) analysed different technologies for the construction of roofs in Canada from the perspective of sustainability. They found that roofs incorporating photovoltaic panels are among the best from an environmental perspective. Green roofs have positive environmental impacts, albeit less significant than those obtained with the addition of photovoltaic panels.

Correia Marrana, Silvestre, de Brito \& Gomes (2017) studied a considerable number of flat roofs from an eminently economic perspective, analysing the costs associated to the life cycle. They concluded that the costs of acquisition and execution of materials are the most significant.

Haddad \& Gonçalves de Lassio (2016) studied the environmental impacts of building materials used in the construction of a housing project, through the LCA methodology. The results showed a considerable consumption of non-renewable energy, intensification of global warming and toxicity to human health. 
Monticelli (2010) analysed the environmental performance of structures of light roofs built with new materials (such as ETFE), comparing them with other similar components made with highly transparent materials, in two buildings, applying the LCA methodology.

The choice of the type of roof to be selected for a building depends on various factors, such as geographic location (which can constrain the roof plan slopes as well as the overlaps between the pieces), whether the roof is to receive any installations, use and purpose of the construction, local customs, square meters to cover, materials available, etc. Nonetheless, factors such as the influence in the environment and sustainability are not usually considered in this selection. As indicated previously, while a number of works analyse different types of roofs in light of the LCA, no other similar studies were found, comparing available roofs and allowing the choose the most adequate in function of various indicators and variables.

This paper's objective is to compare, from a standpoint of sustainability, the environmental impact of various roof construction systems, using techniques based on the LCA and determining for each construction typology various indicators based on socioeconomic and environmental sustainability. The results found could assist decision makers in selecting the most appropriate roof for each building in function of its environmental impact.

\section{Methodology}

In developing this comparative analysis, we used techniques based on the Life Cycle Assessment, considering therefore the ISO-14040:2006 (AENOR, 2006a) and ISO-14044:2006 (AENOR, 2006b) regulations, which envisage dividing the life cycle into various stages. Regulations UNE-EN15804:2012+A1:2014, on sustainability of construction works (AENOR, 2014), and UNE-EN-15978:2012, on assessment of environmental performance of buildings (AENOR, 2012) were also taken into account.

The life cycle assessment is a methodology that characterises and quantifies the various potential environmental impacts, associated to each of the stages of the service life of a product or system.

To determine the influence of roofs' composition from the nature of their various constituent layers, a number of construction solutions were studied. In selecting these roof typologies, we avoided selecting typologies that might contain unconventional elements or solutions, or typologies not commonly used or applicable to housing (such as industrial, commercial or logistical typologies). Moreover, the structural support should be a horizontal concrete slab, which ruled out 'deck' roofs, roofs of attics and mansards, etc. To homogenise the sample, roofs without insulation were not considered.

The flat roofs used are of the kind named 'inverted', which implies the selection of an insulating material with practically null water absorption (closed-cell material) which does not deteriorate with continuous contact with water (Zhukov, Matveev, Aristov \& Pyataev, 2014). In turn, pitched roofs in Spain are mostly made with ceramic roof tiles (normally mixed or roman geometry) (Carretero-Ayuso \& Brito, 2016). Roofs with slates and, to a lesser extent, with cement mortar roof tiles, are also present.

The calculations considered a house situated in the city of Badajoz (Spain), to which is assigned a climate zone of the type C4, according to the Construction Technical Code of Spain (CTE) (Ministerio de la Vivienda, 2006). Based on this regulation, it was verified that the minimum requirements established for the types of materials to be used, their thicknesses, insulation, technical characteristics and layouts were met.

The assumptions are representative of both the usual construction typology in Spain and the average thermohygrometric conditions; as such, the selection of the construction type does not influence the research, and the results can be extrapolated to the entirety of the Spanish territory.

In order to determine the consumption of materials, the period considered by the Spanish regulation (CTE), of an average service life of 50 years, was taken into account. For the evaluation of the transport of materials from the building's location, an average distance of $100 \mathrm{~km}$ was considered and, for the transport and deposit of the produced waste, an average distance of $15 \mathrm{~km}$. For this process, it was considered that the transport is made with trucks using diesel as fuel.

As a unit of reference, $\mathrm{m}^{2}$ were used. For certain indicators, however, it was necessary to assume a construction area of the roof for the calculations, as in the case of the indicators pertaining to preventative maintenance. For these cases, and based on the computer program used, a detached house was considered, with a single floor at the ground level, of 
rectangular geometry, with a built gross floor (and roof) area of $100 \mathrm{~m}^{2}$, with standard accessibility to the constructions site, with a terrain typologies with minimal differences and with a normal-sustained growth of the real estate market.

To determine the embodied energy in the construction (MJ) and the $\mathrm{CO}_{2}$ emission, the BEDEC database of the 'Catalonia Construction Technology Institute' was used (ITEC, 2017). In addition, the waste generated during the process during the construction process was also quantified. This was split into two major groups: 'placement waste' and 'packaging waste'; both being characterised according to the concept of selective separation according to the EWC, European Waste Catalogue (Ministerio de Medio Ambiente, 2002). The classification of 'placement waste' is: materials of cementitious origin -mortar and concrete- (17.01.01), ceramic material from bricks (17.01.02), material from tiles and other ceramic materials (17.01.03), plastics (17.02.03), insulating materials (17.06.04), stony materials -gravel or rock(01.04.08), soil (17.05.04), bituminous mixtures (17.03.02) and mixed waste (17.01.07). The classification of 'packaging waste' is: paper and cardboard packaging (15.01.01), plastics packaging (15.01.02), wooden packaging (15.01.03) and packaging containing residues of or contaminated by dangerous substances (15.01.10).

For each of the constituent layers indicated in Table 2, the quantity of generated waste was determined, according to the BEDEC Database. The waste was characterised according to its nature and recycling potential according to its EWC code, including those materials with dangerous substances or toxicity.

To calculate the cost and the performance of materials and labour necessary for the execution process, the CENTRO price bank was used (COAATGU, 2016).

The total expenses with maintenance throughout a building's service life depend on various factors: type of building, construction unit, quality of the materials, design of the construction solution, form of execution, replacement of vandalised materials, accidents, and attitude of users. For the consideration of the maintenance indicators of each roof variant the data provided by the 'CYPE Engineers' software was used (CYPE, 2017). Once the 'decennial maintenance cost' is known, it is possible to determine the 'maintainability ratio' according to equation 1, which indicates the degree of economic viability of the maintenance in the first ten years of construction.

$$
M R(\%)=\frac{C_{A}}{A \times P}
$$

Where $M R$ is the expressed maintainability ratio (in \%), $A$ is the roof's construction area (in $\mathrm{m}^{2}$ ), $C_{A}$ is the decennial maintenance cost for $A$ (in $€ / \mathrm{m}^{2}$ ) and $P$ is the roof's construction price per unit of area $\left(€ / \mathrm{m}^{2}\right)$.

Throughout this work, a series of roofs with the more common typologies were selected, considering that the definition of each roof results from its constituent layers. In turn, the constituent layers are formed by one or various materials laid out according to the construction system in question. The analysed roofs are shown in Table 1, where their main characteristics, graphical scheme and description are shown. The variant identified as FR-8 (trafficable ventilated flat roof) has been included, despite being seldom built in Spain, aside from specific cases of rehabilitation of historical buildings or special situations, while it is used in other countries.

Table 2 defines and references the constituent layers forming the various types of roofs analysed, composed of the construction typologies which are most representative and usual in Spain. It is considered that the data used in the calculation is reliable, as it originates from three databases that enjoy great prestige in the construction sector in Spain, and are representative of the common construction processes used.

Due to the great variety of HVAC installations which can be used in a building, this parameter was not taken into account during the "use phase", as it would have introduced a complexity of situations, and will be addressed in future research. 


\begin{tabular}{|c|c|c|c|c|c|c|c|c|c|c|}
\hline$\sum_{i}^{0}$ & 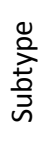 & $\frac{\tilde{n}}{\frac{\pi}{U}}$ & 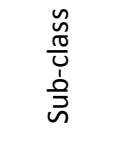 & 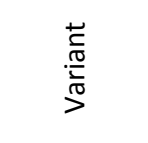 & ర் & Graphical Scheme & 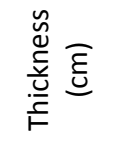 & 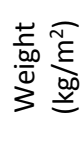 & 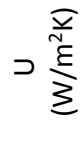 & 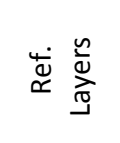 \\
\hline \multirow{8}{*}{ 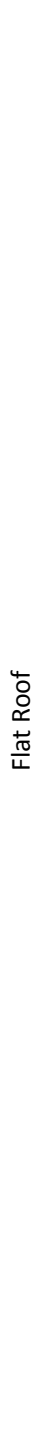 } & \multirow{7}{*}{ 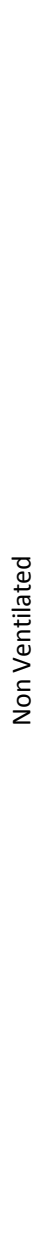 } & \multirow{4}{*}{ 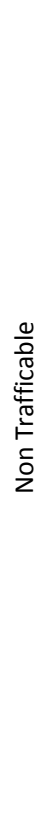 } & \multirow{2}{*}{ 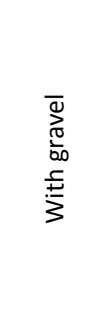 } & $\begin{array}{l}\text { Bituminous } \\
\text { membrane }\end{array}$ & FR-1 & ש: & 30 & 178 & 0.38 & $\begin{array}{c}\mathrm{F} 1+\mathrm{L} 1+ \\
\mathrm{A} 1+\mathrm{S} 1+ \\
\mathrm{P} 1\end{array}$ \\
\hline & & & & $\begin{array}{c}\text { PVC } \\
\text { membrane }\end{array}$ & FR-2 & 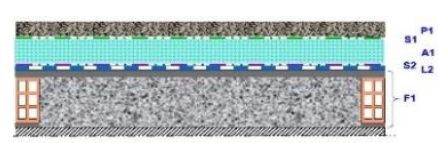 & 30 & 176 & 0.38 & $\begin{array}{c}\mathrm{F} 1+\mathrm{L} 2+ \\
\mathrm{S} 2+\mathrm{A} 1+ \\
\mathrm{S} 1+\mathrm{P} 1\end{array}$ \\
\hline & & & \multirow{2}{*}{ 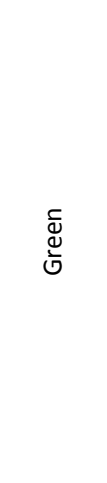 } & $\begin{array}{l}\text { Bituminous } \\
\text { membrane }\end{array}$ & FR-3 & 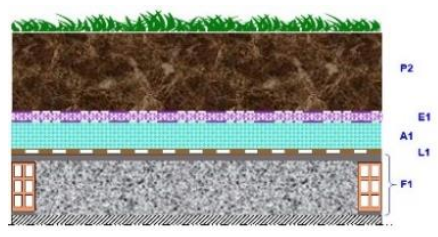 & 65 & 854 & 0.35 & $\begin{array}{c}\mathrm{F} 1+\mathrm{L} 1+ \\
\mathrm{A} 1+\mathrm{E} 1+ \\
\mathrm{P} 2\end{array}$ \\
\hline & & & & $\begin{array}{c}\text { PVC } \\
\text { membrane }\end{array}$ & FR-4 & Wit. & 65 & 852 & 0.35 & $\begin{array}{c}\mathrm{F} 1+\mathrm{L} 2+ \\
\mathrm{S} 2+\mathrm{A} 1+ \\
\mathrm{E} 1+\mathrm{P} 2\end{array}$ \\
\hline & & \multirow{3}{*}{ 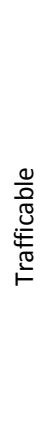 } & \multirow{2}{*}{ 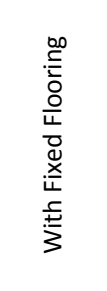 } & $\begin{array}{l}\text { Bituminous } \\
\text { membrane }\end{array}$ & FR-5 & 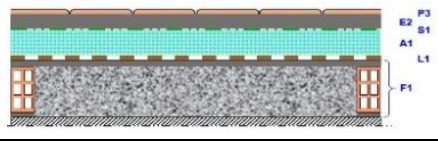 & 30 & 185 & 0.37 & $\begin{array}{c}\mathrm{F} 1+\mathrm{L} 1+ \\
\mathrm{A} 1+\mathrm{S} 1+ \\
\mathrm{E} 2+\mathrm{P} 3\end{array}$ \\
\hline & & & & $\begin{array}{c}\text { PVC } \\
\text { membrane }\end{array}$ & FR-6 & 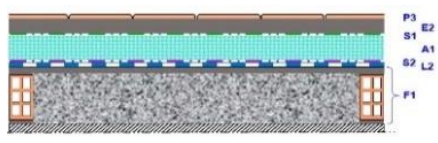 & 30 & 183 & 0.37 & $\begin{array}{l}\mathrm{F} 1+\mathrm{L} 2+ \\
\mathrm{S} 2+\mathrm{A} 1+ \\
\mathrm{S} 1+\mathrm{E} 2+ \\
\quad \mathrm{P} 3\end{array}$ \\
\hline & & & 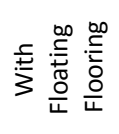 & $\begin{array}{c}\text { PVC } \\
\text { membrane }\end{array}$ & FR-7 & $\mathrm{m}$ & $\begin{array}{c}14 \\
+ \text { air gap }\end{array}$ & 101 & 0.40 & $\begin{array}{c}\mathrm{E} 3+\mathrm{S} 1+ \\
\mathrm{L} 2+\mathrm{S} 2+ \\
\mathrm{A} 1+\mathrm{E} 4\end{array}$ \\
\hline & 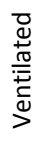 & 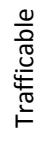 & 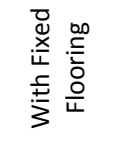 & $\begin{array}{l}\text { Bituminous } \\
\text { membrane }\end{array}$ & FR-8 & 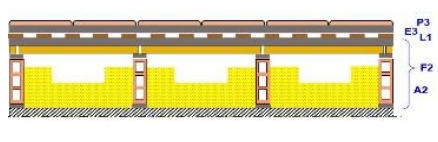 & $\begin{array}{c}17 \\
+ \text { air gap }\end{array}$ & 126 & 0.40 & $\begin{array}{c}\mathrm{A} 2+\mathrm{F} 2+ \\
\mathrm{L} 1+\mathrm{E} 3+ \\
\text { P3 }\end{array}$ \\
\hline \multirow{3}{*}{ 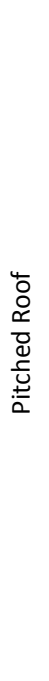 } & \multirow{3}{*}{ i } & \multirow{2}{*}{ 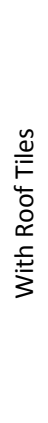 } & 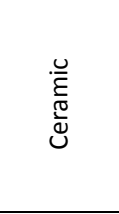 & -- & PR-1 & 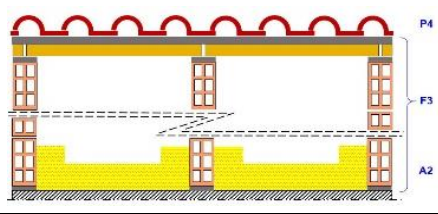 & $\begin{array}{c}24 \\
+ \text { air gap }\end{array}$ & 199 & 0.38 & $\begin{array}{c}\mathrm{A} 2+\mathrm{F} 3+ \\
\mathrm{P} 4\end{array}$ \\
\hline & & & $\sum_{\substack{\frac{1}{2} \\
\frac{0}{0}}}$ & -- & PR-2 & 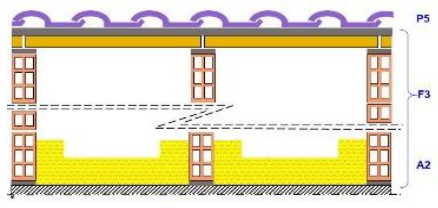 & $\begin{array}{c}21 \\
+ \text { air gap }\end{array}$ & 204 & 0.39 & $\begin{array}{c}\mathrm{A} 2+\mathrm{F} 3+ \\
\mathrm{P} 5\end{array}$ \\
\hline & & 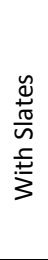 & i & -- & PR-3 & 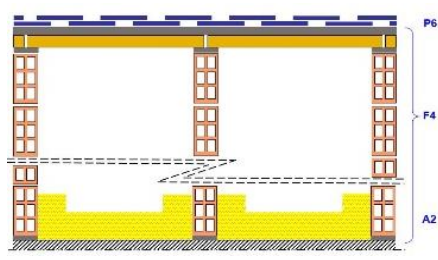 & $\begin{array}{c}15 \\
+ \text { air gap }\end{array}$ & 217 & 0.39 & $\begin{array}{c}\mathrm{A} 2+\mathrm{F} 4+ \\
\mathrm{P} 6\end{array}$ \\
\hline
\end{tabular}


Table 2. Characteristics of the typologies of the constituent layers of the roofs (source: self-elaboration based on the systems included in the Catalogue of Construction Elements of the Technical Code of Spain).

\begin{tabular}{lc}
\hline Group & $\begin{array}{c}\text { Constitue } \\
\text { layer }\end{array}$ \\
\hline $\begin{array}{l}\text { Slope Formation } \\
\text { (G/SF) }\end{array}$ & $\begin{array}{c}\text { Support ro } \\
\text { plan }\end{array}$ \\
& \\
& Panel + \\
& lightened \\
& partition \\
(low slop
\end{tabular}

Construction description

Ref.

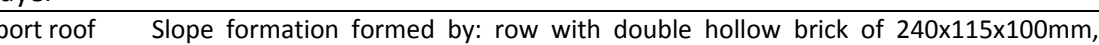

placed in roof valleys, roof hips and ridges; cellular concrete layer of density of $300 \mathrm{~kg} / \mathrm{m}^{3}$, with $15 \mathrm{~cm}$ average thickness, with darbyed finish; finishing with $2 \mathrm{~cm}$ of portland cement mortar with limestone and sand with $250 \mathrm{~kg} / \mathrm{m}^{3}$ of cement, with a volume ratio of $1: 6$ and $5 \mathrm{~N} / \mathrm{mm}^{2}$ of compressive strength.

Panel + Slope formation for slopes of 3\%, formed by: low height lightweight openwork brick partition, made with single hollow bricks of $290 \times 140 \times 40 \mathrm{~mm}$, placed on cement-limecement paste; dove-tailed ceramic panel with $500 \times 200 \times 30 \mathrm{~mm}$ and joints filled with quick-setting cement paste, supported by the lightweight openwork brick partitions; finishing with $2 \mathrm{~cm}$ of portland cement mortar with limestone and sand with $250 \mathrm{~kg} / \mathrm{m}^{3}$ of cement, with a volume ratio of $1: 6$ and $5 \mathrm{~N} / \mathrm{mm}^{2}$ of compressive strength.

Panel + Slope formation for slopes of $30 \%$, formed by: medium height lightweight openwork

lightened partitions (medium slope) brick partition, made with double hollow bricks of $230 \times 110 \times 70 \mathrm{~mm}$, placed on cement-lime-sand mixed mortar with a ratio of 1:2:10, with upper finishing of quicksetting cement paste; dove-tailed ceramic panel with $1000 \times 300 \times 40 \mathrm{~mm}$ and joints filled with on quick-setting cement paste, supported by the lightweight openwork brick partition; finishing with $2 \mathrm{~cm}$ of portland cement mortar with limestone and sand with $250 \mathrm{~kg} / \mathrm{m}^{3}$ of cement, with a volume ratio of $1: 6$ and $5 \mathrm{~N} / \mathrm{mm}^{2}$ of compressive strength.

Panel + Slope formation for slopes of $60 \%$, formed by: high height lightweight openwork lightened partitions (high slope) brick partition, made with double hollow bricks of $230 \times 110 \times 70 \mathrm{~mm}$, placed on cement-lime-sand mixed mortar with a ratio of 1:2:10, with upper finishing of quicksetting cement paste; dove-tailed ceramic panel with $1000 \times 300 \times 40 \mathrm{~mm}$ and joints filled with on quick-setting cement paste, supported by the lightweight openwork brick partition; finishing with $2 \mathrm{~cm}$ of portland cement mortar with limestone and sand with $250 \mathrm{~kg} / \mathrm{m}^{3}$ of cement, with a volume ratio of $1: 6$ and $5 \mathrm{~N} / \mathrm{mm}^{2}$ of compressive strength.

\begin{tabular}{ll}
\hline Insulation & XPS Insulation \\
(G/IL) & MW Insulation
\end{tabular}

(XPS) of $80 \mathrm{~mm}$ thickness (with compressive strength of $300 \mathrm{kPa}$ ).

Insulation with glass mineral wool felt (MW) of $80 \mathrm{~mm}$ thickness, with tarred kraft paper, adhering to one of its sides.

\begin{tabular}{lc}
\hline $\begin{array}{l}\text { Waterproofing } \\
\text { (G/WP) }\end{array}$ & $\begin{array}{c}\text { Bituminous } \\
\text { Membrane }\end{array}$ \\
& PVC Membrane \\
\hline $\begin{array}{l}\text { Independization } \\
\text { and Separation } \\
\text { (G/IS) }\end{array}$ & $\begin{array}{c}\text { Geotextile } \\
\text { (medium density) } \\
\text { Geotextile } \\
\text { (high density) }\end{array}$ \\
\hline $\begin{array}{l}\text { Specific and Special } \\
\text { (G/SS) }\end{array}$ & Drainage panel \\
\end{tabular}

Regularisation

layer of $4 \mathrm{~cm}$

Regularisation

layer of $2 \mathrm{~cm}$

Concrete for

filtrating slab

Modified bitumen membrane with polyester felt reinforcement with a density of $160 \mathrm{~g} / \mathrm{m}^{2}$ and weight of $4 \mathrm{~kg} / \mathrm{m}^{2}$, joined at the overlays with a gas blowtorch, placed without adhering to the support.

Flexible $1.2 \mathrm{~mm}$ PVC membrane, with fiberglass mesh reinforcement, joined in the overlays with hot air solder, placed without adhering to the support.

Medium density geotextile $\left(100 \mathrm{~g} / \mathrm{m}^{2}\right)$ formed by a web of non-woven polypropylene fibres, mechanically bonded.

High density geotextile $\left(300 \mathrm{~g} / \mathrm{m}^{2}\right)$ formed by micro-punched felt of non-woven polyester, mechanically shaped.

Drainage retainer polystyrene nodular panel, with two polypropylene geotextiles adhered on both sides, with nodules of $11 \mathrm{~mm}$ in height and a compressive strength of $710 \mathrm{kN} / \mathrm{m}^{2}$, with overflows in the upper part, placed without adhering.

In situ regularisation layer, improvement and support for pavement, prepared with cement mortar in a $1: 6$ ratio and $4 \mathrm{~cm}$ thickness.

In situ regularisation layer, improvement and support for pavement, prepared with cement mortar in a $1: 6$ ratio and $2 \mathrm{~cm}$ thickness.

Layer of porous filtrating concrete with $3.5 \mathrm{~cm}$ thickness shaped on pre-fabricated flooring tiles places on height-adjustable cylindrical plastic supports, placed in the corners, forming a piece with the insulation placed underneath.

\begin{tabular}{|c|c|c|c|}
\hline $\begin{array}{l}\text { Finishing and } \\
\text { Protection }\end{array}$ & River gravel & $\begin{array}{l}\text { Protection layer with } 5 \mathrm{~cm} \text { thickness, composed of pebbles (loose river stones) of } \\
\text { between } 16 \text { and } 32 \mathrm{~mm} \text { diameter, placed without adhering. }\end{array}$ & P1 \\
\hline \multirow[t]{5}{*}{ (G/FP) } & Vegetable soil & $\begin{array}{l}\text { Layer with } 40 \mathrm{~cm} \text { thickness, composed of landscaping vegetable soil (high category), } \\
\text { provided in bags. }\end{array}$ & $\mathrm{P} 2$ \\
\hline & $\begin{array}{l}\text { Ceramic } \\
\text { flooring tiles }\end{array}$ & $\begin{array}{l}\text { External pavement with mechanically produced ceramic flooring tiles, } 30 \times 30 \mathrm{~cm} \text { in } \\
\text { size, placed with cement based adhesive and finished in its tail-ends between joins } \\
\text { with a liquid paste of cement with additives. }\end{array}$ & P3 \\
\hline & Ceramic roof tile & $\begin{array}{l}\text { Ceramic roof tile (mixed or roman type) of red colour, } 43 \times 26 \mathrm{~cm} \text { in size, placed with } \\
\text { a fresh mortar of cement and river sand. }\end{array}$ & P4 \\
\hline & Mortar roof tile & $\begin{array}{l}\text { Mortar roof tile of compact cement or of pre-fabricated micro-concrete (wavy or } \\
\text { double-roman type) of red colour, } 42 \times 33 \mathrm{~cm} \text { in size, placed with a fresh mortar of } \\
\text { cement and river sand. }\end{array}$ & P5 \\
\hline & Slate roof tile & $\begin{array}{l}\text { Square slate roof tile with } 4 \mathrm{~mm} \text { thickness, higher quality, } 40 \times 20 \mathrm{~cm} \text { in size, placed } \\
\text { with } 80 \mathrm{~mm} \text { long stainless steel hooks. }\end{array}$ & P6 \\
\hline
\end{tabular}


For a better interpretation of the figures found, the studied indicators were grouped according to their environmental and socio-economic contribution.

\section{Environmental indicators}

\section{Embodied energy and $\mathrm{CO}_{2}$ emissions ( $I_{1}$ and $\left.I_{2}\right)$}

The energy effort required to transform raw materials into a construction material is a good environmental indicator. The embodied energy of each of the 20 typologies of constituent layers analysed (categorised by construction functional groups) is expressed in Table 3, measured by unit of area.

It is noted that the constituent layer requiring the least amount of energy in the process is S1 (medium density geotextile) as it is formed by a single material of very low thickness. On the contrary, the E4 constituent layer (concrete for filtrating $s(a b)$ is the one with the highest value due to the amount of energy required to manufacture it with porous concrete and later shape the pre-fabricated pieces. The second constituent layer with a highest value is F4 (Panel + lightened partitions with high slope) as it is composed of three construction elements (partition walls, panel and regularisation layer) and various materials (bricks, ceramic roofing panels, cement and sand); furthermore, as the lightweight aggregate blocks have a slope of $60 \%\left(30.96^{\circ}\right)$, it is necessary to place a significant amount of materials.

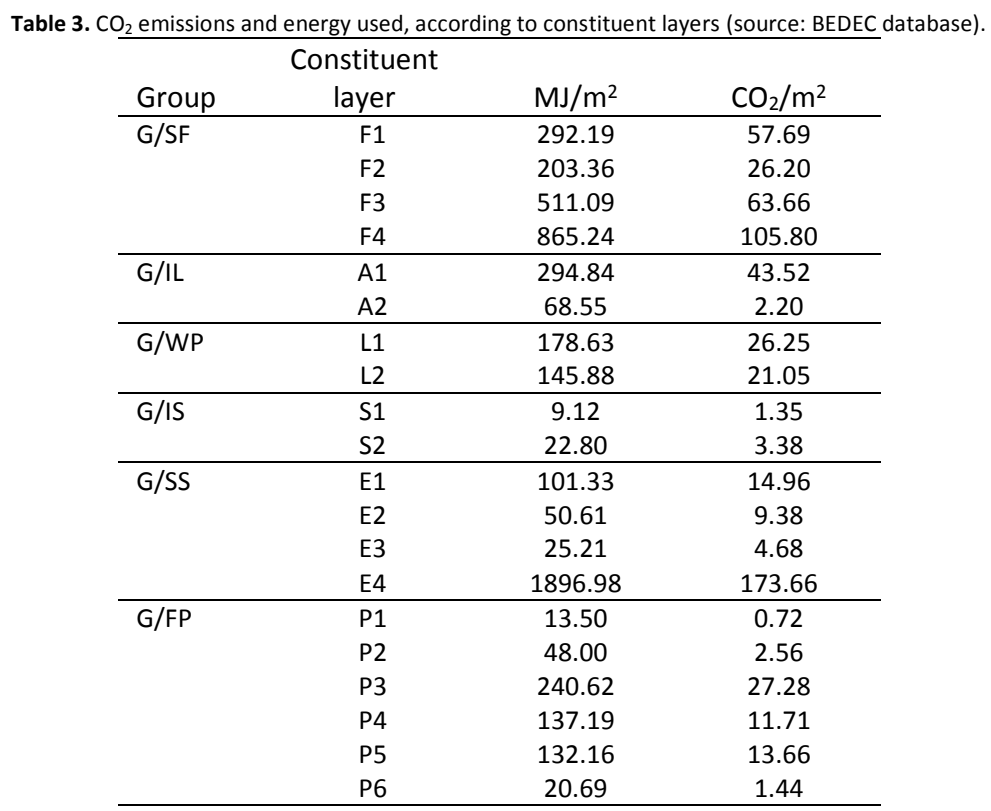

The embodied energy and $\mathrm{CO}_{2}$ emissions were also calculated for the 11 variants of roofs analysed, as shown in Figure 1 , for which the individual figures of the constituent layers of each roof were summed. Sorting the roofs descendingly, according to MJ used, we obtain: FR-7, FR-5, FR-6, PR-3, FR-3, FR-4, FR-1, FR-2, PR-1, FR-8 and PR-2. The cause for which FR-7 has the highest figure is related mostly to the energy necessary to produce the E4 layer; it is, therefore, the least 'energetically sustainable'. The reason for which FR-5 has the second highest figure has to do with the fact that it is comprised of 3 layers that require a great amount of energy for manufacturing.

If roofs are sorted descendingly by the $\mathrm{CO}_{2}$ equivalents in kilograms, we obtain: FR-7, FR-5, FR-6, FR-3, FR-4, FR-1, FR-2, PR-3, FR-8, PR-2 and PR-1. Therefore, the first, second and third positions (FR-7, FR-5 and FR-6) match the sorting by MJ; PR-3 moves from fourth to eighth position; FR-3, FR-4, FR-1, FR-2 move together to one position higher; PR-2 moves from last to penultimate position and PR-1 moves from antepenultimate to last position. The constituent layers with a highest impact on FR-7, FR-5 and FR-6's $\mathrm{CO}_{2}$ emissions are E4, F1 and A1. 
Figure 1. The roofs' energy use and $\mathrm{CO}_{2}$ emissions (source: self-elaboration).

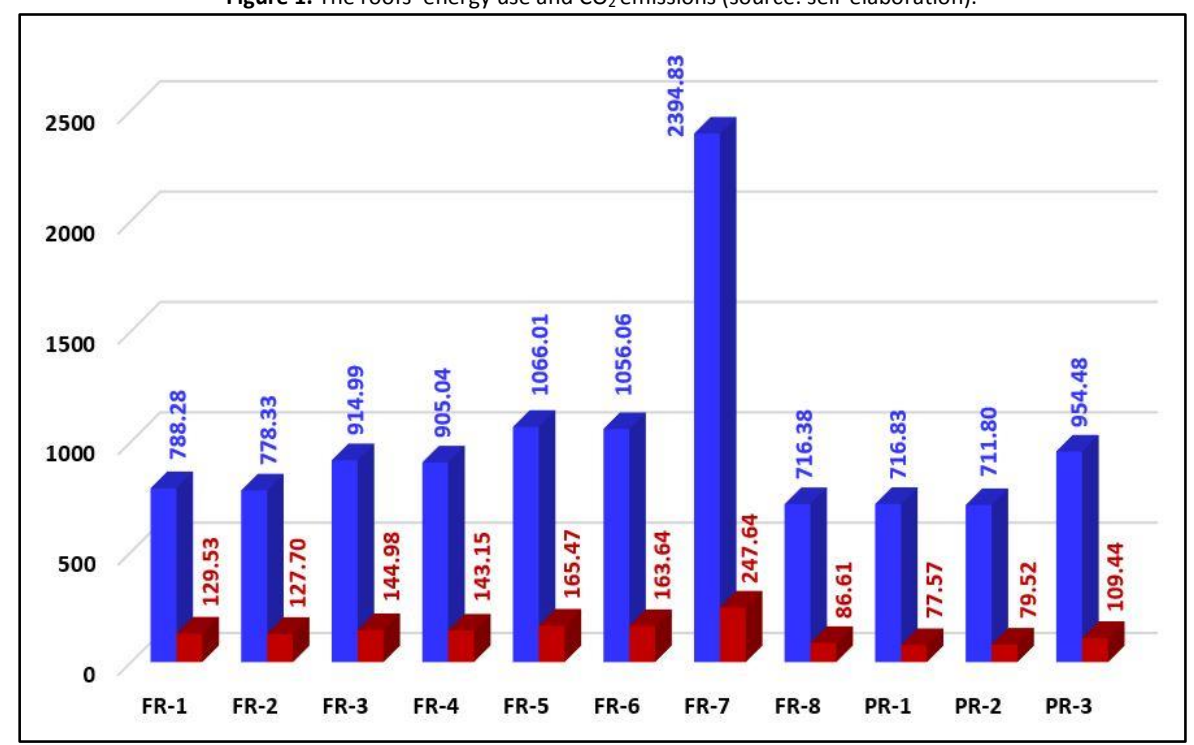

\section{Waste generation $\left(I_{3}\right.$ and $\left.I_{4}\right)$}

The waste resulting from the construction process, generated for each construction typology, is shown in Figure 2a. In turn, the waste generated from packaging is shown in Figure $2 b$.

Adding both types of waste together, the ranked classification of the roofs, sorted descendingly, would be: PR-3, PR-2, PR-1, FR-7, FR-8, FR-5, FR-3, FR-6, FR-4, FR-1 and FR-2. This implies that, taking into account both types of waste together, all variants of pitched roofs generate a much higher quantity of waste $\left(>13 \mathrm{~kg} / \mathrm{m}^{2}\right)$, while flat roofs generally have lower figures.

Figure 2a. Waste generated during placement $\left(\mathrm{kg} / \mathrm{m}^{2}\right)$ (source: self-elaboration).

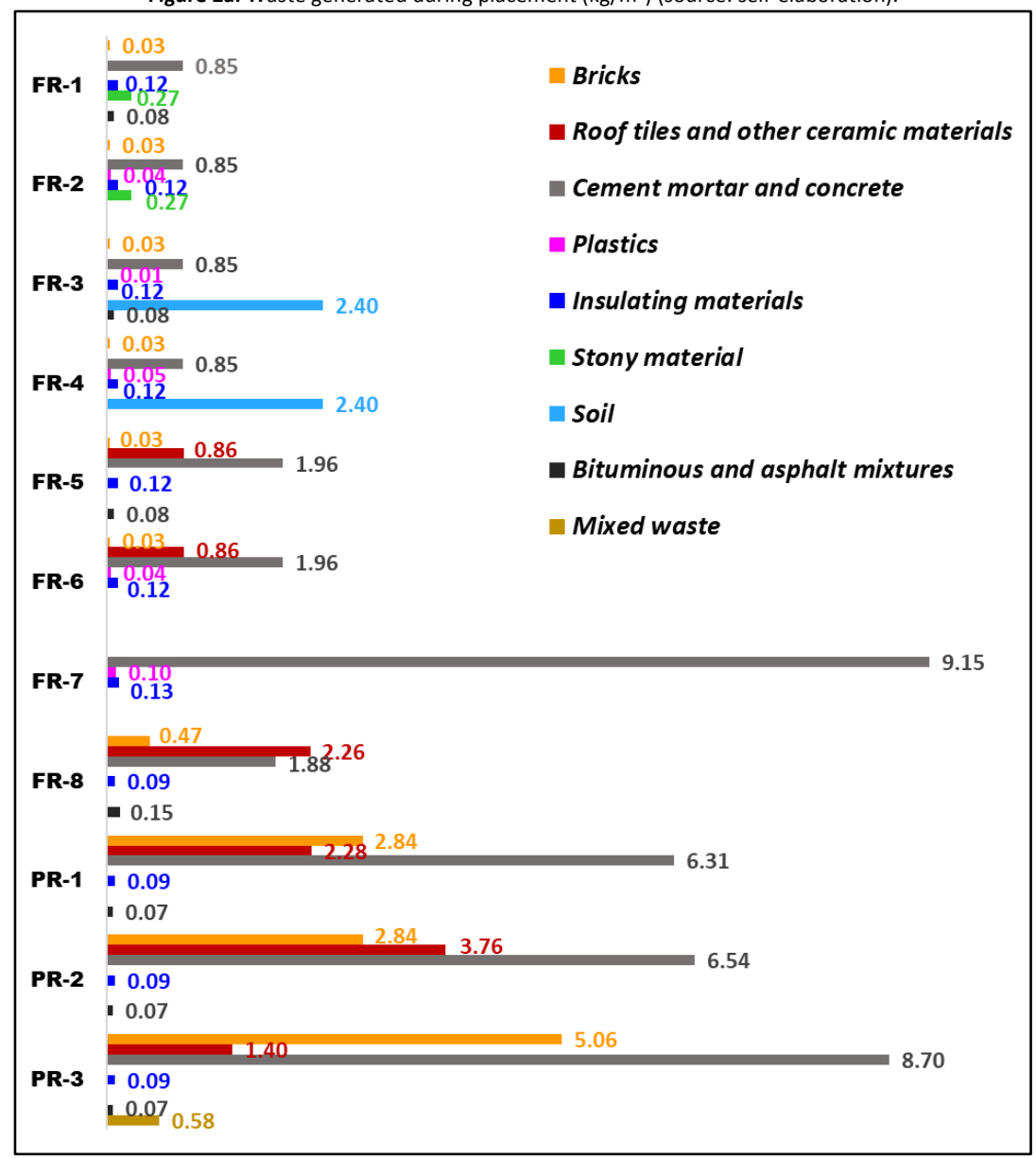


Figure $\mathbf{2 b}$. Waste generated by the packaging process $\left(\mathrm{kg} / \mathrm{m}^{2}\right)$ (source: self-elaboration).

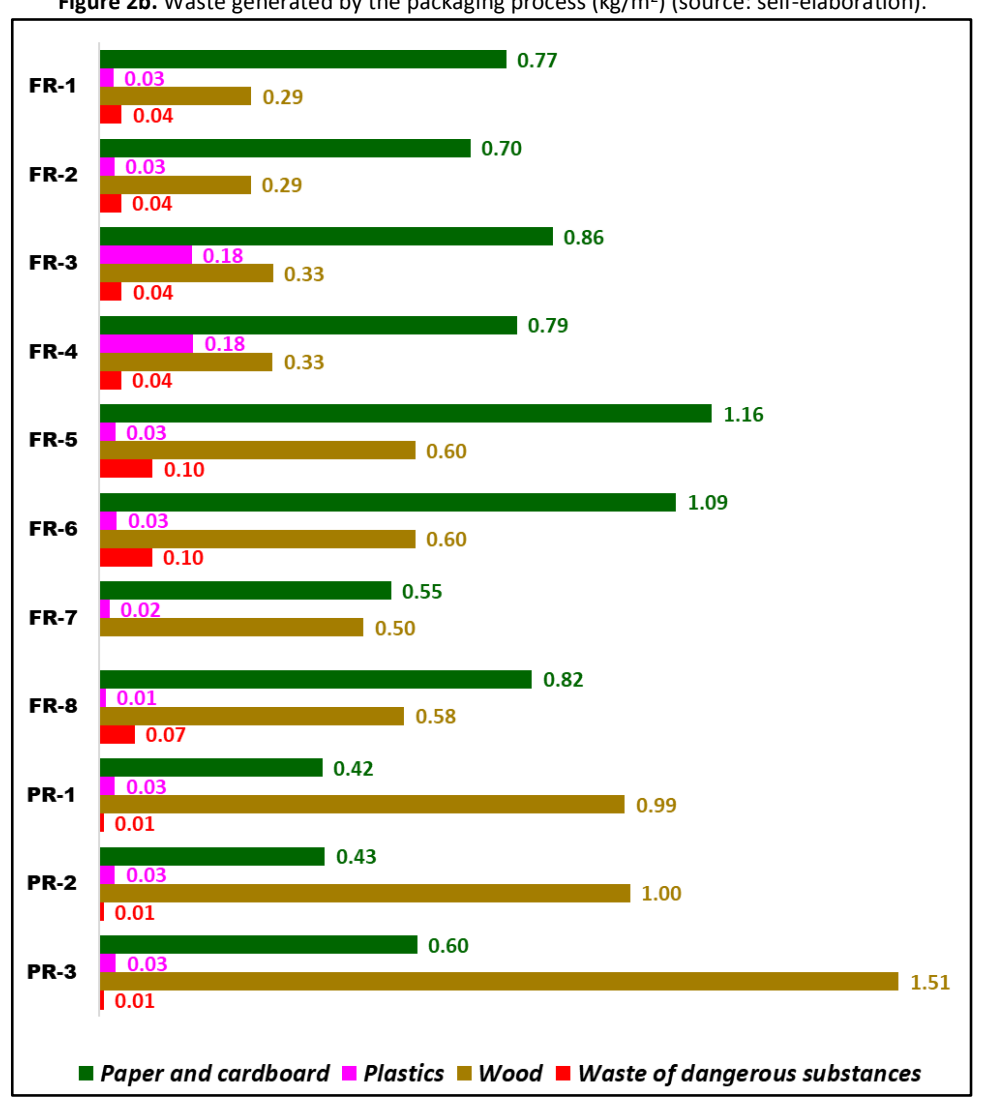

\section{Socio-economic indicators}

\section{Cost of execution (15)}

The economic cost of the various roofs studied was determined, per unit of area $\left(\mathrm{m}^{2}\right)$ (Figure 3). According to this quantification, the roof with the highest cost is PR-2 and the one with the lowest cost is FR-1. The 'cost of labour' and 'cost of materials' were also calculated, and the said Figure shows the cost in euros and the percentage which these aspects represent with regard to the total amount by $\mathrm{m}^{2}$. It is noted that in flat roofs the proportion of the 'cost of materials' is higher than that of 'cost of labour', except in FR-8, whose construction technique is similar to that of pitched roofs. In turn, PR-3 is the only one pitched roof where the percentage of the 'cost of materials' is higher than that of the 'cost of labour', even if quite close to one another.

Figure 3. Cost of execution of the roofs by $\mathrm{m}^{2}$, with the breakdown of labour and material (source: self-elaboration).

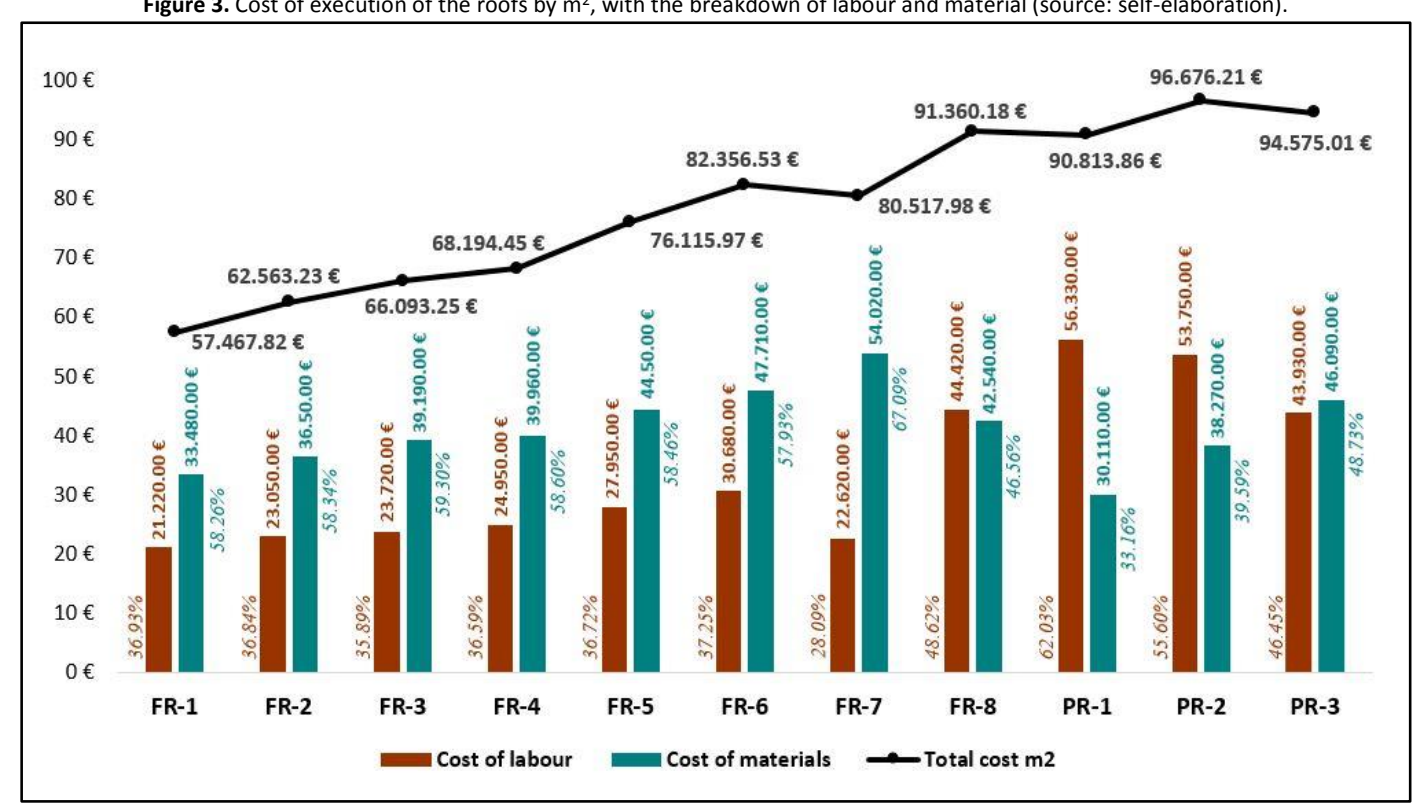




\section{Time invested by labour (I6)}

The 'invested time' in the construction of each of the roofs was evaluated, per unit of area. The hours worked by various workers were added together: foremen, builders and apprentices. The results are shown in Table 4. The highest figures were obtained in pitched roofs with tiles (PR-1 and PR-2).

Table 4. Time invested by labour in each of the roofs (source: self-elaboration).
\begin{tabular}{cc} 
Roof & Hours $/ \mathrm{m}^{2}$ \\
\hline FR-1 & 1.43 \\
FR-2 & 1.55 \\
FR-3 & 1.59 \\
FR-4 & 1.67 \\
FR-5 & 1.97 \\
FR-6 & 2.06 \\
FR-7 & 1.52 \\
FR-8 & 2.99 \\
PR-1 & 3.80 \\
PR-2 & 3.63 \\
PR-3 & 2.92 \\
\hline
\end{tabular}

\section{Decennial maintenance cost and maintainability ratio $\left(I_{7}\right.$ and $\left.I_{8}\right)$}

For each of the 11 variants of roofs, the decennial maintenance cost and the maintainability ratio were found, as shown in Figure 4. It can be noted that green roofs require a greater and continuous maintenance (FR-3 and FR-4), which contrasts with their lesser emissions of $\mathrm{CO}_{2}$. Noticeably, flat roofs finished with gravel (FR-1 and FR-2) require a lower cost, lower than that of any of the pitched roofs.

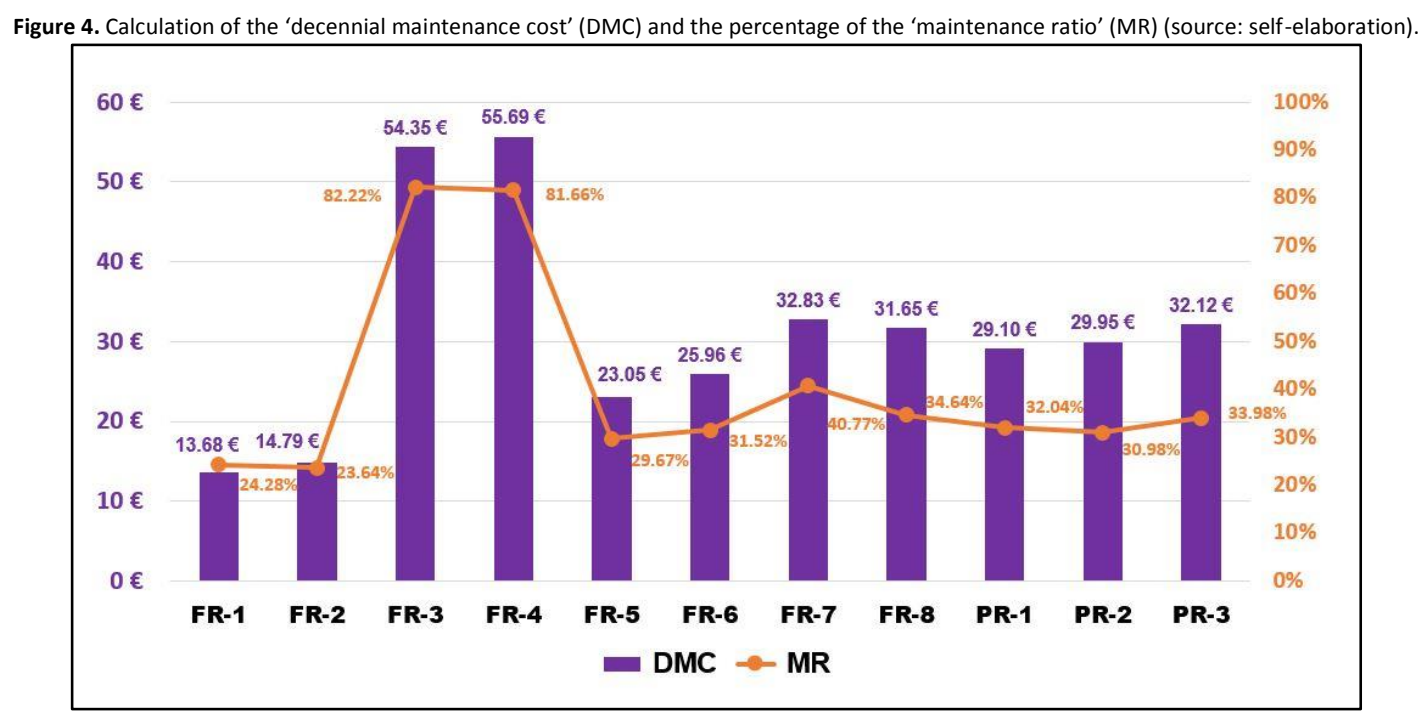

\section{Intrinsic risk of execution $\left(I_{g}\right)$}

To analyse the intrinsic risk of the execution of the works, the work safety conditions necessary to safeguard risk during the works were taken into account. To this end, the process of collecting materials, assembling, placing and using auxiliary means was analysed. Figure 5 shows the figures for this indicator, classified from 0 to 5 , based on a lower or higher risk of work accidents in the construction. It is observed that, in general, pitched roofs have a higher risk in their execution and, as such, require greater preventative measures. 


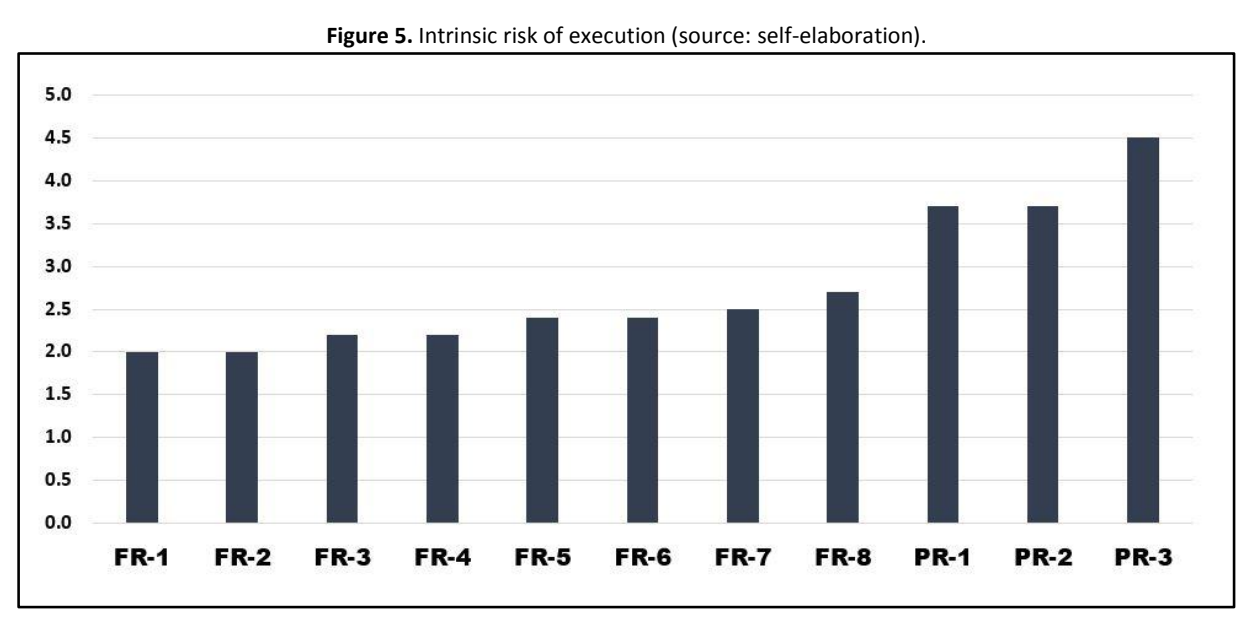

\section{Ranking of the roofs}

Figure 6 shows the 4 environmental and 5 socio-economic indicators of all roofs analysed. To produce this Figure, each indicator's absolute value was divided by the lowest value found in each of the roofs, which would tend towards $100 \%$.

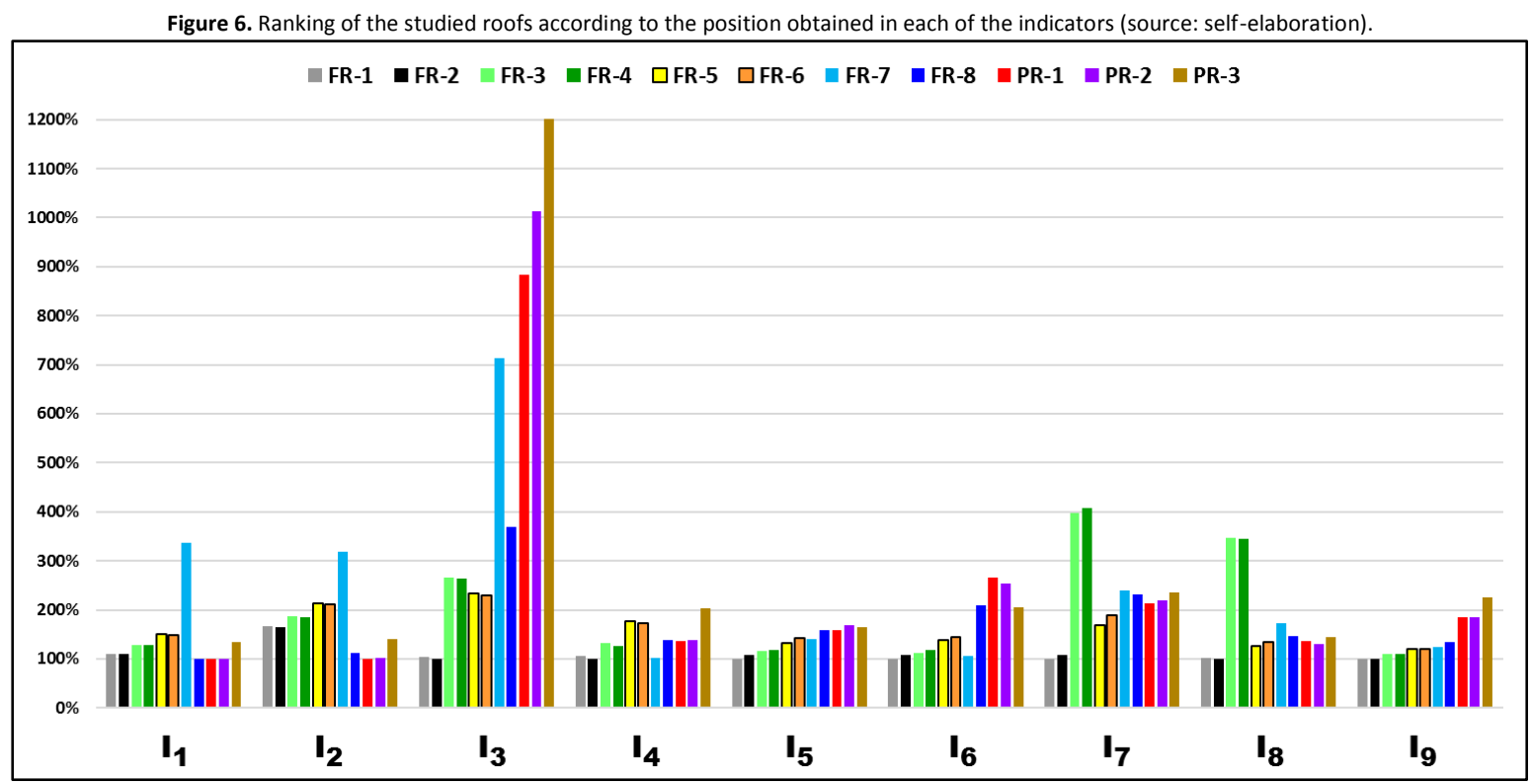

Discussion

It is important to generate tools to facilitate selecting between construction alternatives and choosing different possible solutions based on their environmental impact, as a way to contributing to raising consciousness in the real estate sector and confer upon it an added value. Using the methodology based on the LCA in an early stage of the design, a building's impact throughout its service life will be positively influenced (Pushkar, 2016). This fact will create new opportunities for improvement in the residential sector and, by extension, to society as a whole.

A building's conception phase is crucial to reduce all these types of impacts. The supervision of the designs of projects (Carretero-Ayuso, García-Sanz-Calcedo \& Reyes-Rodriguez, 2016) or of the control of construction deficiencies ( Carretero-Ayuso, Moreno-Cansado \& de Brito, 2017) allows to improve the roofs' construction quality.

In addition, both European and other regulations demand construction works to be carried out with a sustainable use of materials (European Parliament, 2011). Thus, Public Administrations are starting to expect that new works identify their $\mathrm{CO}_{2}$ emissions and the energy use of the products intervening in the construction process. Moreover, building sustainability certifications (BREEAM, DGNB, LEED, among others) and tools such as BIM allow the designer to select different construction solutions according to the environmental impact of the materials used (Candelario-Garrido, García-Sanz-Calcedo \& Reyes-Rodríguez, 2017). 
Materials' duration will be more or less long due to, among other things, the intrinsic properties of the materials themselves and to the quality of the placement in the site itself. The durability of assets is another important added value of a building (Carabaño, Hernando, Ruiz \& Bedoya, 2017).

It was found that flat trafficable roofs emit the most $\mathrm{CO}_{2}$ in their construction, and use the most energy. This is due to needing to use waterproofing layers, both bituminous and in PVC, to guarantee watertightness, whereas pitched roofs do not require waterproofing layers. These layers have a high environmental impact, especially in the manufacturing stage. A future line of work should focus on obtaining more sustainable waterproofing materials.

As for the generation of waste, pitched roofs generate more construction and packaging waste than flat roofs. This is due to more refuse being generated during the construction process, as a consequence of the geometry of the roof, and due to more packaging being used in transporting them.

As for labour, pitched roofs with tiles (PR-1 and PR-2) are those that require the most labour. As a result, designing pitched roofs in countries with cheap labour or with high levels of unemployment is a good strategy, in line with environmental sustainability. Nevertheless, pitched roofs entail greater risks in their execution and, therefore, require additional measures related to health and safety.

The maintainability of the roof is an important parameter that must also be taken into account in the design (GarciaSanz-Calcedo \& Lopez, 2017); it was shown that flat roofs with gravel finishing entail a lower cost of decennial maintainability than pitched roofs. Nevertheless, the consequences of poor maintenance lead to more serious and costly anomalies in flat roofs than in pitched roofs.

The selection of the most suitable roof for a building should also take into account aesthetic, environmental and social factors. The choice of natural products for the roof (such as slate) is a suitable strategy and a means to reduce the environmental impact of the building. Nevertheless, the choice of roof should not be centred only in the methodology developed in this work, and should take other parameters into account. For example, in certain climate zones with a high amount of snowfall, the choice of construction system should take into account the structural conditions and the overloads generated by the snow, with pitched roofs prevailing over flat roofs in this case. In wooded areas with deciduous trees, as well, pitched roofs should be preferred over flat roofs. On the other hand, for buildings the installations of which are kept on their roofs, the use of flat roofs is preferable (Carretero-Ayuso et al., 2017).

Conclusions

The results show that the LCA methodology is a suitable tool for the choice of most appropriate type of roof based on environmental sustainability criteria. The study of the comparison developed herein will help decision makers in the design process of projects to select the most adequate roof for each building in function of its environmental and social impact. Moreover, they will be able to quantify the environmental and socio-economic impact which any change to a project's construction units may imply, and objectively decide the changes which can be made to minimise such an impact.

This research strengthens the criteria to be considered in residential buildings in their design stage, taking into account the environmental impact of the materials to be employed and the efficient use of energy. Based on this, it will be possible to more consciously choose the constituent layers and the more adequate construction variants, minimising the impact and accomplishing a more sustainable building stock.

It was found that pitched trafficable roofs have the highest emissions of carbon dioxide and use the most energy in their construction process; furthermore, flat roofs with gravel finishing have a lower cost of decennial maintenance than pitched roofs.

As for the generation of waste, pitched roofs generate a higher quantity of construction and packaging waste than flat roofs. They also require a higher quantity of labour, especially in the case of pitched roofs with tiles (PR-1 and PR-2). On the other hand, pitched roofs have a higher risk of execution.

Trafficable roofs with floating flooring and PVC membrane (FR-7) generate the highest impact, due to the energy and emissions associated with the manufacturing, transportation and packaging of the constituent materials. Green roofs demonstrated good environmental performance, although entailing high maintenance costs and more labour. 
Taking all analysed indicators into account, the roofs were sorted - from greater to lesser sustainability -as follows: non trafficable flat roofs, both with waterproofing with PVC membrane (FR-2) as with bituminous membrane (FR-1). These are followed by pitched roofs with mortar roof tiles (PR-2) and ceramic roof tiles (PR-1), green roofs with PVC membrane (FR-4), trafficable ventilated flat roof (FR-8) and green roof with bituminous membrane (FR-3). Finally, we have trafficable flat roofs with fixed flooring and PVC membrane (FR-6), pitched roofs with slates (PR-3), trafficable flat roofs with fixed flooring and bituminous membrane (FR-5) and, lastly, trafficable flat roofs with floating flooring and PVC membrane (FR-7).

AENOR. (2006a). Norm UNE-EN-ISO-14040:2006 Environmental Management - Life Cycle Assessment - Principles and Framework. Madrid. Available online at: http://www.aenor.es/aenor/normas/normas/fichanorma.asp?tipo=N\&codigo=N0038060\#.WrBEvqjwZpg

AENOR. (2006b). Norm UNE-EN-ISO-14044:2006 Environmental Management - Life Cycle Assessment - Requirements and Guideline. Madrid. Available online at: http://www.aenor.es/aenor/normas/normas/fichanorma.asp?tipo=N\&codigo=N0038060\#.WrBEvqjwZpg

AENOR. (2012). Norm UNE-EN-15978:2012 Sustainability of construction works - Assessment of environmental performance of buildings - Calculation method. Madrid. Available online at: http://www.aenor.es/aenor/normas/normas/fichanorma.asp?tipo=N\&codigo=N0049397\#.WrAZp5ch1pg

AENOR. (2014). Norm UNE-EN-15804:2012+A1:2014 Sustainability of construction works - Environmental product declarations - Core rules for the product category of construction products. Madrid. Available online at: http://www.aenor.es/aenor/normas/normas/fichanorma.asp?tipo=N\&codigo=N0052571\#.WrAaTZch1pg

Baño-Nieva, A., and Vigil-Escalera del Pozo, A. (2005). Sustainable Construction Guide, ISTAS, Madrid. Available online at: http://bases.bireme.br/cgibin/wxislind.exe/iah/online/?IsisScript=iah/iah.xis\&src=google\&base=REPIDISCA\&lang=p\&nextAction=Ink\&exprSearch=174414\&indexSearch=I D

Belando, J., and López-Mesa, B. (2010). Use of the life cycle assessment (LCA) in the selection of flat roofs in buildings. XIV Congreso Internacional de Proyectos de Ingeniería, 30, 1351-1364. Available online at: http://www.redalyc.org/html/1276/127651042002/

Bludau, C., and Schunck, E. (2010). Flat Roof Construction. Flat Roof Construction Manual: Materials, Design, Applications, Detail Ed., Institut für Internationale Architektur-Dokumentation, Munich, 98-117.

Candelario-Garrido, A., García-Sanz-Calcedo, J., Reyes-Rodríguez, A.M. (2017). A quantitative analysis on the feasibility of 4D planning graphic systems versus conventional systems in building projects. Sustainable Cities and Society, 35, 378-384. DOI: 10.1016/j.scs.2017.08.024

Carabaño, R., Hernando, S.M., Ruiz, D., Bedoya, C. (2017). Life Cycle Assessment (LCA) of building materials for the evaluation of building sustainability: the case of thermal insulation materials. Revista de la Construcción, 16(1). DOI: 10.7764/RDLC.16.1.22

Carretero-Ayuso, M. J., and Brito, J. d. (2016). Mutiparameter Evaluation of the Deficiencies in Tiled Pitched Roofs. Journal of Performance of Constructed Facilities, DOI: 10.1061/(ASCE)FC.1943-5509.0000962,04016097.

Carretero-Ayuso, M. J., Moreno-Cansado, A., de Brito, J. (2017). Study of the Prevalence of Critical and Conflict-Prone Points in Facades. Engineering Failure Analysis, 75, 15-25. DOI: 10.1016/j.engfailanal.2016.12.009.

Carretero-Ayuso, M. J., García-Sanz-Calcedo, J., Reyes-Rodriguez, A. M. (2016). "Qualitative and Quantitative Analyses on Project Deficiencies in FlatRoof Design in Extremadura, Spain". Journal of Construction Engineering and Management, DOI: 10.1061/(ASCE)CO.1943-7862.0001176.

Carretero-Ayuso M.J., Moreno-Cansado A., García-Sanz-Calcedo J. (2017). An Analysis of Technical Facilities Failures in Modern Spanish Houses. Building Services Engineering Research and Technology, 38(4),490-498. DOI: 10.1177/0143624417701802.

COAATGU. (2016). CENTRO Price Bank, Data of Buildings and Urbanisation. Asociación profesional de Aparejadores y Arquitectos Técnicos de la provincia de Guadalajara, Guadalajara (Spain). <http://preciocentro.com; April 2018>.

Contarini, A., and Meijer, A. (2015). LCA Comparison of Roofing Materials for Flat Roofs. Smart and Sustainable Built Environment, 4(1), 97-109.

Correia Marrana, T., Silvestre, J. D., de Brito, J., Gomes, R. (2017). Lifecycle Cost Analysis of Flat Roofs of Buildings. Journal of Construction Engineering and Management. DOI: 10.1061/(ASCE)CO.1943-7862.0001290.

Cubi, E., Zibin, N. F., Thompson, S. J., Bergerson, J. (2015). Sustainability of Rooftop Technologies in Cold Climates: Comparative Life Cycle Assessment of White Roofs, Green Roofs, and Photovoltaic Panels. Journal of Industrial Ecology. DOI: 10.1111/jiec.12269.

CYPE. (2017). Measurements Calculator and Price Generator. CYPE Ingenieros, Alicante. Available online at: http://www.generadordeprecios.info; April 2018>.

Chau, C., Hui, W., Ng, W., Powell, G. (2012). Assessment of CO2 Emissions Reduction in High-Rise Concrete Office Buildings using Different Material use Options. Resources, Conservation and Recycling, 61, 22-34.

Chenani, S. B., Lehvävirta, S., Häkkinen, T. (2015). Life Cycle Assessment of Layers of Green Roofs. Journal of Cleaner Production, 90, 153-162.

European Parliament. (2011). Regulation 305/2001, of 9 March, which establishes the harmonised conditions for the commercialisation of construction products, and repeals Directive 89/106/CEE. Available online at: http://eur-lex.europa.eu/legalcontent/en/ALL/?uri=CELEX:31989L0106

Fayos Ortega, H. (2013). Environmental and Economic Comparison of the Life Cycle of Flat Roofs, Master's degree in energy efficiency and sustainability Ed., Universitat Jaume I, Castellon. Spain. 
Garcia-Sanz-Calcedo, J., Lopez-Rodriguez, F. (2017). Analysis on the Performance of a High Efficiency Administrative Building in Spain. International Journal of Green Energy, 14-1, DOI: 10.1080/15435075.2016.1234379

Graus, R. (2005). La Cubierta Plana, Un Paseo Por Su Historia. Universidad Politécnica de Cataluña. Spain. Available online at: http://upcommons.upc.edu/bitstream/handle/2117/1470/2005+la+cubierta+plana+un+paseo+por+su+historia++ramon+graus.pdf;jsessionid=89148B38B403ACAF8F59083164EC4A91?sequence=1

Haddad, A.N., Gonçalves de Lassio, J.G. (2016). Life cycle assessment of building construction materials: case study for a housing complex. Revista de la Construcción, 15 (2), 69-77.

ITEC. (2017). Structured Database Of Construction Elements -BEDEC-. Instituto de Tecnología de la Construcción de Cataluña, Barcelona. Available online at: http://metabase.itec.cat/vide/es/bedec; April 2018

Lamnatou, C., and Chemisana, D. (2015). Evaluation of Photovoltaic-Green and Other Roofing Systems by Means of ReCiPe and Multiple Life Cyclebased Environmental Indicators. Building and Environment, 93, 376-384.

Ministerio de Medio Ambiente (2002). Order MAM/304/2002, On Operations of Valorisation and Elimination of Waste and the European Waste Catalogue (EWC). Available online at: https://www.boe.es

Ministerio de la Vivienda. (2006). CTE - Construction Technical Code [Royal Decree 314/06]. Available online at: https://www.codigotecnico.org

Monticelli, C. (2010). Environmental assessment of ultralight roof structures built with new materials: The case of the ETFE cushions. Proceedings of IASS WG18 Colloquium. Available online https://www.researchgate.net/profile/Carol_Monticelli/publication/279759100_Environmental_assessment_of_ultralight_roof_structures_b uilt_with_new_materials_the_case_of_the_etfe_cushions/links/559a5a1808ae21086d25e802.pdf

Peri, G., Traverso, M., Finkbeiner, M., Rizzo, G. (2012). Embedding 'substrate' in Environmental Assessment of Green Roofs Life Cycle: Evidences from an Application to the Whole Chain in a Mediterranean Site. Journal of Cleaner Production, 35, 274-287.

Pushkar, S. (2016). Life Cycle Assessment of Flat Roof Technologies for Office Buildings in Israel. Sustainability, 8(1), 54; DOI:10.3390/su8010054

Saiz, S., Kennedy, C., Bass, B., Pressnail, K. (2006). Comparative Life Cycle Assessment of Standard and Green Roofs. Environmental science \& technology, 40(13), 4312-4316.

Vieira Lopes, and Thais. (2014). Telhado verde, energia embutida e emissão de CO2: uma análise comparativa a sistemas de cobertura convencionais. Curitiba: Universidade Tecnológica Federal do Paraná. Available online at: http://repositorio.roca.utfpr.edu.br/jspui/handle/1/3441

Zhukov, A., Matveev, A., Aristov, D., Pyataev, E. (2014). Extruded Polystyrene Foam in Flay Roofs., 17-31. Available online at: http://web.a.ebscohost.com/abstract?direct=true\&profile=ehost\&scope=site\&authtype=crawler\&jrnl=23055502\&AN=98183157\&h=KUnbczF 4ezoLEfs7npqDJeXojut23r6KWhdqxdRrOf2iYiVYQkqocLaXe8HpxA3rAhDJuG\%2bk5hWa6ulOIrpvnw\%3d\%3d\&crl=c\&resultNs=AdminWebAuth\& resultLocal=ErrCrINotAuth\&crlhashurl=login.aspx\%3fdirect\%3dtrue\%26profile\%3dehost\%26scope\%3dsite\%26authtype\%3dcrawler\%26jrnl\%3 d23055502\%26AN\%3d98183157 